\title{
Collaborative procurement strategies for infrastructure projects: a multiple-case study
}

Per Erik Eriksson MSc, PhD

Professor of Entrepreneurship and Innovation, Department of Business

Administration, Technology and Social Sciences, Luleå University of

Technology, Luleå, Sweden; KTH Royal Institute of Technology, Stockholm, Sweden (Orcid:0000-0002-1746-2637)

\section{Leentje Volker MSc, PhD}

Professor of Integrated Project Delivery, Department of Civil Engineering, Group of Construction Management and Engineering, University of Twente, Enschede, the Netherlands (corresponding author:

I.volker@utwente.nl) (Orcid:0000-0003-2766-3763)

Anna Kadefors MSc, PhD

Professor of Real Estate Management, Department of Real Estate and Construction Management, KTH Royal Institute of Technology, Stockholm, Sweden; Chalmers University, University of Technology, Gothenburg, Sweden (Orcid:0000-0001-5608-5013)
Sofia Lingegård MSc, $\mathrm{PhD}$

Researcher in Sustainable Procurement, Department of Sustainable Development, Environmental Science and Engineering (Seed), School of Architecture and the Built Environment, KTH Royal Institute of Technology, Stockholm, Sweden (Orcid:0000-0002-6682-9239)

Johan Larsson MSc, PhD

Senior Lecturer in Construction Management and Building Technology, Department of Civil, Environmental and Natural Resources Engineering, Luleå University of Technology, Luleå, Sweden

(Orcid:0000-0001-9524-4814)

Lilly Rosander MSc

$\mathrm{PhD}$ candidate in Sustainable Procurement, Department of Real Estate and Construction Management, KTH Royal Institute of Technology, Stockholm, Sweden (Orcid:0000-0002-2981-4185)

With the announcement to tender a project, several strategic decisions are made that have significant impact on the innovation and efficiency potential of a project. The purpose of this study is to investigate and compare how different types of integrative and collaborative procurement strategies may enhance the opportunities for improved efficiency and innovation in infrastructure projects. Hence, it contributes to the scientific debate on buyer-supplier relationships in relation to project performance. Furthermore, it guides public client organisations in steering explicitly for integration and innovation in their projects. Interview-based case studies of ten public infrastructure projects procured based on four different types of collaborative procurement strategies in Sweden and the Netherlands were conducted. The findings indicate that the duration of the collaboration is fundamental in setting the limits for innovation and that early involvement and long-term commitments in maintenance open up opportunities for more innovation. Naturally, the potential for increased efficiency is higher than for innovation and also occurs in collaborations with limited duration. The findings confirm the importance of a learning perspective on procurement strategies for public client organisations and show the importance of explicit considerations on incentives and project governance issues in the front-end phase of a project.

\section{Introduction}

Many scholars argue that there is a lack of innovation and adoption of new technology in the infrastructure sector (e.g. Rose and Manley, 2012, 2014; Tawiah and Russell, 2008). Others have discussed the commonality of cost and time overruns stemming from efficiency problems (e.g. Cantarelli et al., 2012; Han et al., 2009; Winch, 2013). Collaboration aspects could arguably affect both these alleged challenges related to innovation and efficiency shortcomings. Due to the interorganisational nature of construction projects and their inherent complexity, innovation in the construction industry requires knowledge integration and collaboration across numerous actors and their activities (Harty, 2005; Kähkönen, 2015; Rose and Manley, 2012). Furthermore, the typical short-term and arm's-length relationships within the industry result in disruptive learning curves, which are detrimental to efficiency (Eriksson, 2013). As also recognised in several policy reports (e.g. WEF, 2016), interorganisational collaboration can therefore be considered as a core mechanism for improving efficiency and innovation. The exact impact of these mechanisms is, however, hard to study because of the complex, long-term and dynamic nature of projects in construction. This complicates the learning process of client organisations in steering on specific project outcomes by strategic procurement decisions.
Traditionally, procurement strategies involve competitive tendering based on detailed and strict contracts and subsequent control and surveillance. Recent studies, however, advocate that complex infrastructure projects need new types of management practices, promoting a more flexible way to deal with change by collaborative teams rather than strict planning and control (Gransberg et al., 2013; Koppenjan et al., 2011). Some nontraditional strategies focus on client-contractor collaboration (e.g. Bresnen and Marshall, 2002), while others emphasise supply chain collaboration and integration by performance-based delivery models that may also comprise maintenance and financing (e.g. Lenferink et al., 2012; Verweij, 2015). Although such procurement strategies are not new to some countries and industry segments, infrastructure clients in many European countries have been slow to adopt such non-traditional practices (Eriksson et al., 2017a).

In this paper, case studies of ten recent and ongoing infrastructure projects in Sweden and the Netherlands are presented. The purpose of the study is to investigate and compare how different types of integrative and collaborative procurement strategies may enhance the opportunities and incentives for improved efficiency and innovation in infrastructure projects. Furthermore, challenges and perceived barriers to implementing these strategies are 
identified and discussed. This knowledge contributes to the scientific debate on buyer-supplier relationships in relation to project performance and provides a learning perspective on integrative and collaborative procurement strategies for public client organisations. The findings also enable project managers and procurement professionals to steer on innovation and efficiency by making explicit decisions that set the formal and informal governance of the project organisation.

\section{Theoretical framework}

2.1 Organisational learning for innovation and efficiency Following the seminal work of March (1991), the organisational learning literature typically distinguishes between two main learning modes: exploration and exploitation. Eriksson et al. (2017b: p. 23) emphasise that 'explorative learning involves a distant search for, and assimilation of, new knowledge and technologies to enhance creativity, and to achieve innovation and radical development of new solutions'. Exploitative learning, instead, is 'based on local search for familiar knowledge and technologies to deepen the current knowledge set and achieve efficiency through incremental development and continuous improvements of existing solutions' (Eriksson et al., 2017b: p. 23). Due to their inherent differences, these two learning modes are difficult to combine and manage together, particularly in organisational settings with scarce resources, such as project organisations (Gupta et al., 2006). However, prior research has indicated that in projects both short-term efficiency based on exploitative learning and more radical innovation based on explorative learning can be facilitated by interorganisational collaboration (Eriksson, 2013; Eriksson et al., 2017b).

Construction projects are often complex and uncertain endeavours that require creative problem-solving and explorative learning to manage innovation and adaptation challenges. Several scholars point towards the important role of sense-making in this context (Fellows and Liu, 2016; Volker, 2012). Furthermore, the nature of innovations and technology development in construction entails that numerous interdependent components and subsystems must be coordinated (Harty, 2005). Hence, project actors need to collaborate in joint development processes (Bosch-Sijtsema and Postma, 2009; Larsson and Larsson, 2018; Ozorhon, 2013) for innovations to be accepted and implemented successfully. In addition, exploitative interproject learning is necessary in construction projects to achieve efficient use of limited resources (Eriksson and Leiringer, 2015). However, knowledge is often context specific, which makes it difficult to transfer across projects due to varying personal, professional and organisational interests (Bresnen et al., 2003; Hartmann and Dorée, 2015). Accordingly, there are many explorative and exploitative learning challenges that are related to the alleged innovation and efficiency shortcomings in the construction industry.

\subsection{Procurement strategies}

In construction management literature and practice, the client's contracting and procurement strategies are typically argued to set a basis for collaboration among project actors. Based on the work of
Eriksson et al. (2017b), four core procurement strategy components can be distinguished: $(a)$ the delivery system, including the nature and timing of the contractor involvement; $(b)$ the reward system; (c) the contractor selection procedures; and $(d)$ the collaboration model. The components may be combined in different ways in order to achieve a governance structure that fits project characteristics.

Important integrative collaborative project delivery models are design-build (DB), early contractor involvement (ECI), design-build-maintain (DBM) and design-build-finance-maintain (DBFM). While the traditional design-bid-build (DBB) contracts integrate the client and designer competences, the basic idea of DB contracts is that there is no separation between design and construction that hampers constructability. The contractor then has more freedom to develop technical solutions that improve time and cost efficiency. However, neither DB nor DBB contracts (in their traditional form) promote collaboration between the client and the contractors since they separate, allocate and clarify the actors' different responsibilities in order to make the contracts more transparent from the client perspective (Eriksson et al., 2017a). An ECI contract engages the contractor earlier than a DB contract normally would and particularly suits situations in which the uncertainty is too high to calculate a price in the tendering stage and where the client sees important benefits in involving the contractor in very early design stages to improve constructability by integrating design and production knowledge (Lenferink et al., 2012; van Wijck, 2018). DB contracts may also be integrated with maintenance services or private funding. Such integrated DBM or DBFM contracts are associated not only with other business models of infrastructure projects, but also with improved efficiency and innovation (e.g. Roumboutsos and Saussier 2014; Verweij, 2015).

With regard to the reward system, fixed-price payment has been most common in both DB and DBB contracts when the client wants to ensure that the lowest price is obtained through competitive tendering (Eriksson et al., 2017a). However, this reward system is a poor basis for client-contractor collaboration, as the client has no incentive to support the contractor in costsaving development work and the contractor has incentives to lower the quality of the end product if it saves costs. Incentivebased payment can enhance project actors' motivation for joint innovation work and is therefore considered suitable when contractors are procured early and involved in the design stage (Rose and Manley, 2012).

Contractor selection can be based on lowest bid competitive tendering which relies on the idea that a large number of bidders who compete on the basis of price will ensure that the client can minimise their investment costs for the project. This selection model may work satisfactorily in rather simple and straightforward projects with low uncertainty, where $(a)$ the competences and experiences of the contractors are of little importance and $(b)$ the bid price will remain close to the end price due to low degree of changes. A strategy that is based on prequalification of a lower number of capable contractors and 
subsequent bid evaluation that also takes into account 'softer' criteria (e.g. organisation, experience and reference projects) may enhance collaboration (Kadefors et al., 2007; Volker, 2012). Such partner selection may also promote joint innovation work because the client can select a contractor that is capable and willing to engage in such joint development (Eriksson et al., 2017a).

An important element of collaborative procurement strategies is to utilise a collaboration model that includes several integrative activities and technologies. Examples of integrative activities and technologies are co-location in a joint project office (Alderman and Ivory, 2007; Bresnen and Marshall, 2002; Gil, 2009), joint information technology tools (Eriksson, 2015; Johansen et al., 2005), formulation of joint objectives and continuous follow-up meetings (Bayliss et al., 2004; Eriksson, 2015) and team-building activities (Caniels et al., 2012; Martinsuo and Ahola, 2010). Such integrative activities and technologies strengthen the socialisation of partners so that they can establish a collaborative climate that serves as a foundation for joint development efforts.

\subsection{Dimensions of collaboration and supply chain integration}

Collaboration can be considered a multidimensional concept that can be divided into four dimensions: scope, depth, duration and intensity (Eriksson, 2015). These dimensions are interconnected and affected by the procurement strategy. Collaboration scope involves the nature and number of companies involved in the integrated supply chain (Fabbe-Costes and Jahre, 2007). In construction projects, it refers to which organisations are involved in and jointly perform the integrative activities and technologies for example, clients, suppliers, contractors and consultants (Eriksson, 2015). Collaboration depth refers to the integration of different types of professionals and functions at different hierarchal levels within each partner organisation (Eriksson, 2015).

The duration dimension is dependent on the length of the time period during which the partners will collaborate and jointly utilise integrative activities and technologies, which could include integration across subsequent projects and/or project stages (Eriksson, 2015). Hence, collaboration duration is strongly linked to the delivery system which decides in what stages of a project the contractor will be involved. The intensity dimension measures the degree or strength of integration, which is dependent on the extent to which integrative activities and technologies are utilised (Fabbe-Costes and Jahre, 2007; Flynn et al., 2010). Prior research on partnering arrangements emphasises the importance of intense or strong collaboration, which is heavily affected by the implemented procurement strategy, in particular the collaboration model (e.g. Bayliss et al., 2004; Eriksson, 2015).

\section{Research approach}

\subsection{Case selection and case characteristics}

The paper draws on a multiple-case study of ten infrastructure projects in Sweden and the Netherlands, with four types of collaborative procurement strategies (DB, ECI, DBM and DBFM). Case studies were considered a suitable method to approach this research because of the complexity of integrated project environments and the need for in-depth understanding of the dynamics between the project delivery model, dimensions of collaboration and the performance-related factors. The cases could provide rich empirical descriptions of the particular setting occurring in infrastructure projects (Stake, 1995). The number of ten cases falls within the optimal range recommended by Eisenhardt (1989). With fewer than four case studies, the empirical grounding of the research is likely to be unconvincing, and, with more than ten cases, it may be difficult to manage the complexity and volume of data.

The case studies were performed in the context of the Procurement for Sustainable Innovation in the Built Environment (ProcSIBE) research programme, a Swedish research initiative on procurement for sustainable innovation in the built environment. This programme also includes Dutch-Swedish knowledge exchange. Accordingly, the authors have studied two Swedish DB projects, two Swedish ECI projects, three Swedish DBM projects and three Dutch DBFM projects. The DBM and DBFM projects were selected because the implementation phase started 8-15 years ago and all are currently in the maintenance phase. This means that the actual impact of the delivery model should more or less be visible now. The DB and ECI projects were selected because of their explicit focus on integration and collaboration. They were still in the engineering or construction phase at the time of data collection. All projects were pilots or early applications of the delivery and contract models in their respective contexts. This means that, in most cases, clients and contractors consider the implementation of these relatively new procurement strategies as an exploration process. Because these integrated procurement strategies have not been in use for such a long time, these projects provide the best data available thus far to assess the impact of such collaborative and integrative agreements on efficiency and innovation. Table 1 presents the details of the cases.

All Swedish projects were procured by the Swedish Transport Administration (STA). Traditionally, STA has primarily used DBB contracts but has adopted a policy to increase the share of DB contracts significantly. Basic collaborative models with integrative activities have been used since the early 2000 s, but the two ECI projects were the first to be defined as high collaboration. The DB projects were studied during the construction phase. DB 1 can be considered a conventional road project worth around $€ 21$ million, whereas DB 2 is a subproject in a megarailway project estimated at $€ 190$ million. In both projects, procurement was based on an open bid invitation and evaluation based on the lowest price. They include a reward system based on fixed price. In both projects, the contractors were procured after a predesign phase in which a large part of all permits for the stretch had been applied for and approved.

The ECI projects were two railway projects that were parts of the same complex urban megaproject and estimated at $€ 300$ million and $€ 430$ million. The contractors were procured at an early stage 
Table 1. Overview of cases per delivery method

\begin{tabular}{|c|c|c|c|c|c|c|}
\hline $\begin{array}{l}\text { Project/ } \\
\text { delivery } \\
\text { model }\end{array}$ & Description & $\begin{array}{l}\text { Contract } \\
\text { sum: } € \\
\text { millions }\end{array}$ & Duration & Reward system & Contractor selection & Collaboration \\
\hline DB 1 & Road project & 21 & 2016-2017 & Fixed price & $\begin{array}{l}\text { Open bid invitation and } \\
\text { evaluation based on the } \\
\text { lowest price }\end{array}$ & $\begin{array}{l}\text { Basic collaboration model. A few } \\
\text { collaborative activities and } \\
\text { technologies }\end{array}$ \\
\hline DB 2 & $\begin{array}{l}\text { Railway as part } \\
\text { of a } \\
\text { megaproject }\end{array}$ & 190 & 2014-2018 & Fixed price & $\begin{array}{l}\text { Open bid invitation and } \\
\text { evaluation based on the } \\
\text { lowest price }\end{array}$ & $\begin{array}{l}\text { Basic collaboration model. A few } \\
\text { collaborative activities and } \\
\text { technologies }\end{array}$ \\
\hline $\mathrm{ECl} 1$ & $\begin{array}{l}\text { Railway as part } \\
\text { of a } \\
\text { megaproject }\end{array}$ & 300 & 2018-2026 & $\begin{array}{l}\text { Cost-plus in stage } 1 \\
\text { and target cost with } \\
\text { gainshare/painshare } \\
\text { in stage } 2\end{array}$ & $\begin{array}{l}\text { Restricted procedure with pre- } \\
\text { qualification and evaluation } \\
\text { based on multiple criteria }\end{array}$ & $\begin{array}{l}\text { High level of collaboration in line } \\
\text { with STA's guidelines. } \\
\text { Co-location and extensive } \\
\text { collaboration activities }\end{array}$ \\
\hline $\mathrm{ECl} 2$ & $\begin{array}{l}\text { Railway station } \\
\text { as part of a } \\
\text { megaproject }\end{array}$ & 400 & 2018-2026 & $\begin{array}{l}\text { Cost-plus in stage } 1 \\
\text { and target cost with } \\
\text { gainshare/painshare } \\
\text { in stage } 2\end{array}$ & $\begin{array}{l}\text { Restricted procedure with pre- } \\
\text { qualification and evaluation } \\
\text { based on multiple criteria }\end{array}$ & $\begin{array}{l}\text { High level of collaboration in line } \\
\text { with STA's guidelines. Co- } \\
\text { location and a few collaboration } \\
\text { activities }\end{array}$ \\
\hline DBM 1 & $\begin{array}{r}\text { Highway } \\
\text { project }\end{array}$ & 58 & $\begin{array}{l}\text { Construction: } \\
\text { 2005-2008 } \\
\text { Maintenance: } \\
\text { 2008-2023 }\end{array}$ & $\begin{array}{l}\text { Fixed price for } \\
\text { investment and yearly } \\
\text { payments for } \\
\text { maintenance }\end{array}$ & $\begin{array}{l}\text { Restricted procedure with pre- } \\
\text { qualification and evaluation } \\
\text { based on multiple criteria }\end{array}$ & $\begin{array}{l}\text { Basic collaboration model. A few } \\
\text { collaborative activities and } \\
\text { technologies }\end{array}$ \\
\hline DBM 2 & Road project & 130 & $\begin{array}{l}\text { Construction: } \\
\text { 2010-2013 } \\
\text { Maintenance: } \\
\text { 2013-2033 }\end{array}$ & $\begin{array}{l}\text { Fixed price and yearly } \\
\text { payments for } \\
\text { maintenance }\end{array}$ & $\begin{array}{l}\text { Restricted procedure with pre- } \\
\text { qualification and evaluation } \\
\text { based on the lowest price }\end{array}$ & $\begin{array}{l}\text { Basic collaboration model. A few } \\
\text { collaborative activities and } \\
\text { technologies }\end{array}$ \\
\hline DBM 3 & $\begin{array}{c}\text { Highway } \\
\text { project }\end{array}$ & 130 & $\begin{array}{l}\text { Construction: } \\
\text { 2010-2014 } \\
\text { Maintenance: } \\
\text { 2014-2034 }\end{array}$ & $\begin{array}{l}\text { Fixed price and yearly } \\
\text { payments for } \\
\text { maintenance }\end{array}$ & $\begin{array}{l}\text { Restricted procedure with pre- } \\
\text { qualification and evaluation } \\
\text { based on the lowest price }\end{array}$ & $\begin{array}{l}\text { Basic collaboration model. A few } \\
\text { collaborative activities and } \\
\text { technologies }\end{array}$ \\
\hline DBFM 1 & $\begin{array}{c}\text { Highway } \\
\text { project }\end{array}$ & 135 & $\begin{array}{l}\text { Construction: } \\
\text { 2003-2008 } \\
\text { Maintenance: } \\
\text { 2004-2023 }\end{array}$ & $\begin{array}{l}\text { Fixed price and yearly } \\
\text { payments for } \\
\text { maintenance }\end{array}$ & $\begin{array}{l}\text { Restricted procedure with pre- } \\
\text { qualification and evaluation } \\
\text { based on the lowest price }\end{array}$ & $\begin{array}{l}\text { Limited collaboration model. } \\
\text { Limited collaborative activities } \\
\text { and technologies }\end{array}$ \\
\hline DBFM 2 & Road project & 120 & $\begin{array}{l}\text { Construction: } \\
\text { 2012-2015 } \\
\text { Maintenance: } \\
\text { 2015-2034 }\end{array}$ & $\begin{array}{l}\text { Fixed price and yearly } \\
\text { payments for } \\
\text { maintenance }\end{array}$ & $\begin{array}{l}\text { Competitive dialogue and } \\
\text { evaluation based on the } \\
\text { price-quality ratio }\end{array}$ & $\begin{array}{l}\text { Limited collaboration model. } \\
\text { Limited collaborative activities } \\
\text { and technologies }\end{array}$ \\
\hline DBFM 3 & Tunnel project & 700 & $\begin{array}{l}\text { Construction: } \\
\text { 2008-2013 } \\
\text { Maintenance: } \\
\text { 2013-2037 }\end{array}$ & $\begin{array}{l}\text { Fixed price and yearly } \\
\text { payments for } \\
\text { maintenance }\end{array}$ & $\begin{array}{l}\text { Competitive dialogue including } \\
\text { three stages and evaluation } \\
\text { based on the best } \\
\text { price-quality ratio }\end{array}$ & $\begin{array}{l}\text { Limited collaboration model in a } \\
\text { rather formal structure, plus } \\
\text { system-based contract } \\
\text { management }\end{array}$ \\
\hline
\end{tabular}

STA, Swedish Transport Administration

based on a number of soft criteria, such as collaboration skills, experiences and technical skills, and a proposed contractor's fee. A two-stage ECI model was used, and the contractors were engaged by a consultancy contract and reimbursed based on incurred costs for stage 1 . In stage 1, the design is developed jointly by the client and contractor, and, provided that the client finds the design and target cost acceptable, the contractor is re-engaged by a DB contract to accomplish detailed design and construction in stage 2 . The reward system for stage 2 is a targetcost contract with a gainshare/painshare arrangement. The interviews in the ECI projects took place during stage 1 and after contracts had been signed for stage 2 .

The three Swedish DBM projects (two highways worth $€ 58$ million and $€ 130$ million and one road worth $€ 130$ million) were studied in the maintenance phase so that the impact of integrating several phases would be visible. After a restricted tender procedure with pre-qualification and an evaluation based on price, the contracts were awarded to contractors for a period of 18-24 years, whereof 15-20 years consisted of maintenance after construction. In all DBM projects, the reward system is based on fixed-price agreement with yearly payments for maintenance. Additional fees are paid by the contractors in case the roads are closed for maintenance longer than specified in the contracts.

Two of the DBFM projects (a highway worth $€ 135$ million procured in a competitive dialogue and a tunnel worth $€ 700$ million procured in a restricted procedure with pre-qualification) were contracted for a period of 20-30 years by Rijkswaterstaat, the governmental agency responsible for the major infrastructure facilities in the Netherlands. The third project, a provincial road worth $€ 120$ million, was commissioned by Rijkswaterstaat in 
collaboration with a Dutch province by applying a competitive dialogue. In all three cases, contract management was organised by systematic auditing on quality levels. The reward system was based on fixed prices with incentives for early delivery and yearly performance-based maintenance payments.

\subsection{Data collection and data analysis}

The empirical data underpinning this paper ranged from two to seven interviews per project, with respondents in managerial positions (e.g. director, project, manager, contract manager and stakeholder manager) representing the main parties (client, consultant and contractor) in the ten projects. In addition, project documents, such as organisation schemes, contracts and tendering documents, were investigated. The interviews dealt with the procurement history, the level of collaboration and the project governance structure. The authors also addressed the outcomes of the project in terms of innovation and efficiency-related aspects. Each interview took $1-2 \mathrm{~h}$ in the presence of one or two members of the research team and was transcribed verbatim. This led to a total data set of 44 interviews underpinning this paper. In some projects, written evaluation reports, observations and case descriptions were available and accessible to the researchers. This information was utilised to triangulate the interview findings.

The analytical framework that underpins this study (see Figure 1) is based on the assumption that the four procurement strategy components - delivery system, reward system, contractor selection and collaboration model - relate to the four dimensions of collaboration: scope, depth, duration and intensity, which in turn influence the perceived project performance in terms of efficiency and innovation-related aspects. The authors systematically analysed the data on these aspects and then searched for common themes. These findings were discussed and validated between the authors. In the following findings section, the authors present the findings on efficiency and innovation potential per procurement strategy.

\section{Findings}

\subsection{Efficiency potential}

In both DB projects, the client initiated a basic collaboration model in the early phases. The model entailed some collaborative tools, such as joint project office, formulation of joint objectives and regular collaboration meetings. This rather high intensity of collaboration had positive effects on the efficiency in both projects, mostly by enabling faster joint decision-making and clearer communication. The co-location of the client and main contractor facilitated informal communication and collaboration among them in both DB projects. In DB 2, construction work took place simultaneously with train traffic in the work area on the existing track, affecting both the work environment and the production planning, which needed to be made minute by minute so that the scheduled train-free time could be used as efficiently as possible. The joint project office has been vital in achieving the goal of zero disruptions in the ongoing train traffic. In both DB projects, working tightly and intensively (in the joint project office) created a commitment in which it is everyone's duty to contribute actually to the best interest of the project. The joint project office also contributed to collaboration depth, which enabled minor problems to be solved quickly on a low hierarchical level, whereas larger ones were brought up to executive level. Particularly in DB 1, such informal decision-making meant that the construction process had seldom been stopped. However, the authors also found that the extensive collaborative activities must be put in relation to the contract sum. DB 1, for example, was almost considered too small for this type of extensive collaborative effort.

In the ECI projects, the early involvement of the contractors implied a longer duration, which enabled the contractors to contribute to increased constructability in design. The total project time could also be shortened, since the two-stage approach allowed the contractor to be involved before all permits were obtained. Further, no technical solutions or cost estimations were required in the tenders, which meant that tendering costs were low, about $10 \%$ of those for a comparable DB project. The two projects were labelled as high collaboration by the client, suggesting high ambitions regarding scope, depth and intensity of collaboration. Co-location was mandatory, partnering facilitators were engaged and collaborative activities were planned. However, collaboration intensity in particular varied between the projects. In ECI 1, collaborative activities and co-location were much appreciated and perceived to enable informal communication and faster joint decision-making. In ECI 2, the intensity of collaboration was lower, mostly due to individuals with traditional

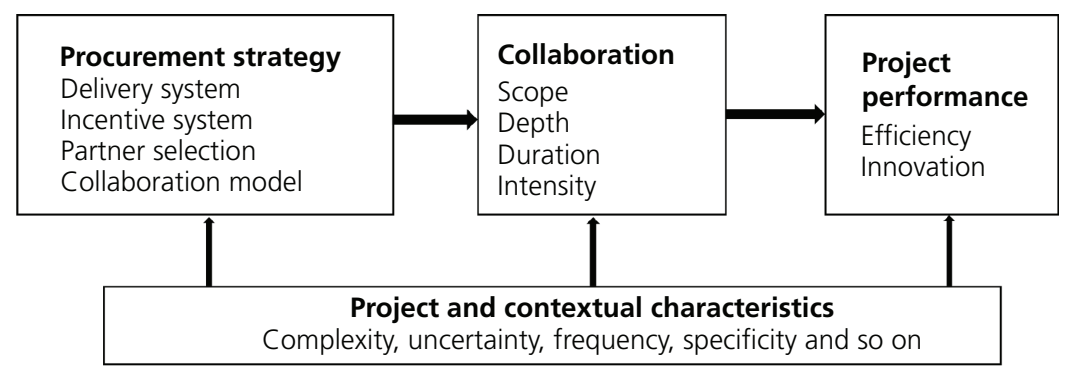

Figure 1. Analytical framework 
(non-collaborative) mindsets holding key positions on both sides. In this case, conflicts hampered efficiency gains and co-location was not fully used. Depth was low on the client side in both projects, and the lack of client resources was perceived to hinder intensity. However, both ECI projects experienced significant challenges in agreeing on a target cost before entering stage 2 . In the end, stage 1 was delayed by more than 9 months for both projects. The gainshare/painshare component was seen more as a risk than an opportunity by contractors, and in the negotiations the sharing ratios were altered, from $50 / 50$ to $90 / 10$ and $80 / 20$.

The authors found that the prolonged duration based on a rather early involvement of the contractors in all four types of contracts has timesaving potential since the integration of design and production makes parallel processes possible. For example, in DBFM 1, the tender resulted in an offer of the contractor that gained 11 months from to the initial planning. Findings from the DBM and DBFM projects illustrate that the long-term responsibilities during operations and maintenance also affect the contractors' priorities regarding quality in relation to the length of the contracts. To some extent, the maintenance responsibility makes contractors invest in materials and technical solutions, with higher quality if they result in a lower lifecycle cost (LCC) for the contract, although they may initially be somewhat more expensive. A remark on this finding is that contractors seem to optimise within the boundaries of the contract and not within the actual life cycle of the product. Findings from DBFM 1 and DBFM 3 indicate that the inclusion of the private funder may result in an economically more sound tender strategy and more solid technical solutions with lower risks. To avoid unnecessary risks, the private funder strongly steers on quality control and assessment of the viability of chosen solutions. Furthermore, the private funder's focus on revenues will put pressure on keeping the time schedule and encouraging early delivery of construction work. The sooner that the construction is finished and the traffic can be released, the sooner the private funder can start earning money.

On the other hand, the DBM and DBFM cases also showed that collaboration between the design and construction actors and the maintenance actors was challenging to achieve. Accordingly, the potential to increase the depth of collaboration was not reached, which affected the maintainability negatively. In the DBM cases, this was due to lack of experience and clear processes for integrating the maintenance experience and perspective in the design stage. For all DBFM cases, the project organisation included at least a dozen different parties, which made transaction costs in the procurement phase high. Approval for significant changes (e.g. the implementation of an innovation) needs to be found among several layers of responsible officers, which takes time. Therefore, the complex organisational set-up of DBFM projects seems to act as a double-edged sword: the decisions taken may be of high quality, but decision-making is slower. Long-term collaborations also create challenges in relation to the ambiguities in contractual agreements since they challenge the collective memory of the organisation. Decisions and discussions made 15 years ago are hard to remember, and most people will not be there during the whole maintenance contract. Hence, it is important to get the documentation right when decisions are taken, in order to prevent ambiguities and conflicts in later maintenance stages. In the DBM cases, the parties have struggled with the type and frequency of the documentation. Due to the length of the contracts, proactive planning regarding documentation is vital.

\subsection{Innovation potential}

Whereas the intensity of collaboration in both DB projects contributed to efficiency, none of them can be considered, however, as innovative. Although the contractor was procured rather early, the fact that many requirements and constraints were already set and fixed limited the contractor's possibilities to affect the development and use of innovative production solutions based on more explorative learning. The fixed-price contract and the design responsibilities also seemed to have deterred the contractor from making innovation efforts with uncertain outcomes. The collaboration may have enhanced, however, some innovation efforts that required the presence of different actors and competences. These innovations were mainly related to product quality. Because of the longer duration of the warranty period (10 years), it was, for example, desirable for all actors to decrease the risk of major maintenance work. This resulted in, for example, higher quality of the asphalt in DB 1. The absence of innovation in DB 2 must be discussed in the light of the actual task to perform. Railway construction is much more regulated in detail than road investments, meaning that the degrees of freedom are small and innovation is most often limited to the planning of work, work methods and some choice of materials.

In the ECI projects, the early involvement of the contractor and collaborative approach enabled different professions to engage in creative processes, which was highly appreciated by project members, such as designing engineers. In ECI 1, the contractor developed a new technical solution that involved a major design change. The change, which was based on the elimination of a bridge, carried considerable environmental benefits, as well as important cost reductions. Such a major design change would not have been possible if the contractor was involved at a later stage. In ECI 2, a full-scale test of alternative diaphragm walls techniques was decided during stage 1 to make it possible to utilise in stage 2. Still, the project team expressed that the time frame of stage 1 (15 months in ECI 1 and 1 year in ECI 2) was rather limited and put high pressure on the project team. Some expressed that stage 1 should be longer in order for the contractor really to have an impact on the design. Nonetheless, there was some level of innovation in both contracts, despite the allegedly limited time frame. However, the lack of incentives for innovation in stage 1 was seen as a problem, and several changes have been made in STA's subsequent ECI projects to incentivise better both efficiency and innovation in this stage.

In some of the other cases, the authors also found that an increased scope of collaboration may enhance some innovation efforts. In DBM 1, the intense collaboration between the client, the consultants and the contractor served as a main driver and enabler for innovation. In DBM 2, the contractor developed some product and process 
innovations that were beneficial for both the client and the contractor In DBFM 3, an innovative asphalt development was realised, and a similar innovation was seen in DBM 3 where the asphalt on the bridges was substituted for concrete. For the DBFM 2 project, a new way of handling the traffic on the adjacent lane was used by the contractor. Also, wider asphalt machines were developed to be able to lay both lanes at the same time and avoid the edge between the lanes, making the road more durable. For the DBM cases, the innovations were more of an incremental type and did not involve any risk-taking from the contractors' side. In retrospect, the client was a bit disappointed regarding the achieved innovations; they had higher hopes for more radical innovations due to the long-term maintenance contract.

Still, findings also indicate that the early involvement of contractors may not be sufficient to facilitate more radical (explorative) and substantive innovations. Too many restrictions are already set during the initial planning and permit processes that are conducted before involvement of contractors. In the DBFM projects, the increased quality control and the risk aversive perspective of the private funder left minimum room for radical innovation. In these projects, the broader scope of collaboration resulted in fewer radical innovations but improved verification of the innovations that were selected and implemented. Contrasting findings from DBM 2 and DBFM 3 indicate the importance of client priorities towards innovation. An ongoing discussion regarding a change to light-emitting diode (LED) lights in DBFM 3 shows that the contractor did not have sufficient financial incentives to change existing techniques, while the client desires this change for environmental reasons. Contrastingly, in DBM 2, the contractor awaited the development of LED and implemented the latest technology in order to fulfil client requirements and reduce the energy costs during the operation and maintenance phase. In this case, the contractor had sufficient incentives to do so, since the switch to a newer technology would decrease the maintenance cost more than it increased the investment cost.

\section{Concluding discussion}

Overall, the findings of this study contribute to the continuous scientific debate within the construction management field on the relation between contracting and project performance. By adopting a wider systemic perspective based on four procurement strategy components and four dimensions of collaboration, this study's findings add more clarifications and holistic understanding of how different contracting and procurement strategies influence performance. In addition, by adopting an organisational learning perspective on both efficiency and innovation aspects, this study adds knowledge to the understanding of project performance, beyond the iron triangle of tome, cost and quality. This is important, particularly from a sustainability perspective, which requires both short-term efficiency and long-term innovation. This study's findings contain practical implications for project managers and procurement professionals by providing guidance on how procurement and collaboration affect specific performance aspects throughout the different phases of infrastructure projects.
More specifically, this work indicates that the duration of the collaboration is fundamental in setting the limits for innovation and that early involvement and long-term maintenance commitments strengthen the potential for more innovation. Naturally, the potential for increased efficiency is higher than for innovation and also occurs in collaborations with limited duration, such as the DB cases. There are, however, many barriers to overcome in fully exploiting the innovation and efficiency potential. Furthermore, the complexity of the underlying mechanisms appears to be difficult to grasp, which limits the learning perspective of client organisations to steer more strategically on these potential project outcomes by integrative and collaborative procurement arrangements. Also, for procurement professionals, project managers and contract managers steering on collaboration and innovation requires awareness of the legal and organisational alternatives that are often decided on at a very early front-end stage of the project (Hoezen and Volker, 2015).

In all four types of collaborative procurement strategies, early involvement of the contractor improved constructability and reduced delivery time due to parallel processes. For maintenance responsibility, the authors' findings align with previous studies, suggesting that $\mathrm{DB}(\mathrm{F}) \mathrm{M}$ contracts encourage stronger focus on quality and LCC. This is because the contractor has strong incentives to reduce maintenance costs arising from poor quality and inferior technical solutions (Lenferink et al., 2012; Rose and Manley, 2012). The authors further found that the involvement of private funding can result in selection of more robust and verified material and technical solutions and that collaboration with design consultants could enhance development efforts. Private investors increase focus on revenues, put pressure on keeping the time schedule and encourage early delivery of the project. The scope, depth and intensity of the collaboration were also important in enhancing efficiency and innovation. In line with prior research (Barnes et al., 2007), the authors found that collaboration at many different hierarchical levels resulted in improved and quicker decision-making in daily work, where co-location in particular was powerful and appreciated. Increased scope by involving design consultants and key subcontractors in collaboration was considered valuable in all projects, and lack of client resources often hampered collaboration.

It is clear that collaboration among different roles and hierarchical levels, long maintenance responsibilities and early involvement of contractors all carry great potential. Decision makers also seem to have high aims and expectations generally regarding such collaboration and integration. This, however, appears to be difficult to achieve fully in practice. The authors' cases have highlighted several organisational, contractual and cultural limitations and barriers. First, legal restrictions from initial planning processes limit possibilities for innovation - for example, sometimes corridors permit only one solution. In this respect, there are often fewer opportunities for design innovation in horizontal infrastructure projects than in vertical building construction projects. Furthermore, lack of time for joint design and development efforts can be a major barrier to innovation. When the financial risk and time pressure are too high, contractors 
Management, Procurement and Law

Volume 172 Issue MP5
Collaborative procurement strategies for

infrastructure projects: a multiple-case

study

Eriksson, Volker, Kadefors et al. will stick to their existing solutions to avoid time-consuming and risky development work based on explorative learning. Other hidden costs include long-term maintenance contracts increasing the need for documentation due to lack of organisational memory, and the increased complexity (depth) of the organisation, which can delay decision processes and raise internal conflicts. Also, it should be acknowledged that improving collaboration intensity by an extensive collaboration model costs more time and money. Thus, there is a delicate balance between positive outcomes and expenses, which has to be considered before deciding on a collaboration model that fits the individual project.

Finally, the authors' findings highlight that the impact of contractual incentives on efficiency and innovation is complex and that there are frequently contradictory effects that may be hard to assess. Some models for early involvement result in increased costs for tendering for the contractor, particularly if a design is proposed and competitive dialogue is used. In the ECI contracts, however, early involvement significantly reduced tendering costs. Long maintenance responsibilities encourage efficiency but could deter radical innovation based on explorative learning due to risk of malfunctions and costlier maintenance. The involvement of private funders could also hamper more radical innovation that entails larger risk. Long-term maintenance contracts are very difficult to price ex ante, which is the reason why contractors need to add risk premiums to their tenders. The longer the duration of maintenance, the more difficult to price and the larger the risk premiums. The results of this study further suggest that target-cost contracts, intended to share risks and create incentives for contractors to be innovative and reduce costs, in effect may counteract collaboration.

With regard to organisational learning, this study identified vital potential improvements of efficiency and innovation as a result of the chosen procurement strategies. The fact that none of the projects studied was part of a long-term contract spanning over a series of projects seems to have hampered efficiency in terms of interproject exploitative learning. This is similar to findings in prior studies of collaborative relationships in the construction industry, suggesting that, even when supply chain partners perform well, the client often switches suppliers between partnering projects (Alderman and Ivory, 2007). Misalignments occurred, for example, in the level of specification in the DB contracts, setting target costs in the ECI contracts, integrating maintenance knowledge in the DBM and DBFM contracts and risk aversion of private investors in the DBFM contract and the contractors in the DBM contracts. Thus, for a public repeat client to realise the full potential of a new strategy, it is important to have a long-term perspective and capabilities to analyse and learn from these experiences (Volker and Hoezen, 2017). However, due to the challenges in reaping all the potential benefits of collaboration, actors need to improve continuously their processes, routines and capabilities for managing the projects. These activities seem to leave little room for organisational learning and could hinder further implementation of integrative and collaborative procurement strategies in infrastructure practice.

\section{Acknowledgements}

The authors gratefully acknowledge the financial funding received from the Swedish Transport Administration and the Swedish Research Council Formas for the ProcSIBE group (2013-1837) and for the research project 'Public procurement strategies for sustainable development in the infrastructure sector' (942-2016126). This publication emerged from a paper presented at the $34 \mathrm{rd}$ Annual Arcom Conference, Belfast UK, and the technical report Efficiency and Innovation in Infrastructure Projects - Four Types of Collaborative Procurement Strategies in Sweden and the Netherlands, which was produced for the International Transport Forum of the Organisation for Economic Co-operation and Development.

\section{REFERENCES}

Alderman N and Ivory C (2007) Partnering in major contracts: paradox and metaphor. International Journal of Project Management 25(4): 386-393, https://doi.org/10.1016/j.ijproman.2007.01.002.

Barnes B, Naudé P and Michell P (2007) Perceptual gaps and similarities in buyer-seller relationships. Industrial Marketing Management 36(5): 662-675, https://doi.org/10.1016/j.indmarman.2006.04.004.

Bayliss R, Cheung S, Suen H and Wong SP (2004) Effective partnering tools in construction: a case study on MTRC TKE contract in Hong Kong. International Journal of Project Management 22(3): 253-263, http://dx.doi.org/10.1016/S0263-7863(03)00069-3.

Bosch-Sijtsema P and Postma T (2009) Cooperative innovation projects: capabilities and governance mechanisms. Journal of Product Innovation Management 26(1): 58-70, https://doi.org/10.1111/j.15405885.2009.00334.x.

Bresnen M and Marshall N (2002) The engineering or evolution of cooperation? A tale of two partnering projects. International Journal of Project Management 20(7): 497-505, https://doi.org/10.1016/ S0263-7863(01)00043-6.

Bresnen M, Edelman L, Newell S, Scarbrough H and Swan J (2003) Social practices and the management of knowledge in project environments. International Journal of Project Management 21(3): 157-166, https:// doi.org/10.1016/S0263-7863(02)00090-X.

Caniels M, Gelderman C and Vermeulen N (2012) The interplay of governance mechanisms in complex procurement projects. Journal of Purchasing \& Supply Management 18(2): 113-121, https://doi.org/10. 1016/j.pursup.2012.04.007.

Cantarelli C, van Wee B, Molina EJE and Flyvbjerg B (2012) Different cost performance: different determinants? The case of cost overruns in Dutch transport infrastructure projects. Transport Policy 22: 88-95, https://doi.org/10.1016/j.tranpol.2012.04.002.

Eisenhardt KM (1989) Building theories from case study research. Academy of Management Review 14(4): 532-550, https://doi.org/10. 5465/amr.1989.4308385.

Eriksson PE (2013) Exploration and exploitation in project-based organizations: development and diffusion of Knowledge at different organizational levels in construction companies. International Journal of Project Management 31(3): 333-341, https://doi.org/10.1016/j. ijproman.2012.07.005.

Eriksson PE (2015) Partnering in engineering projects: four dimensions of supply chain integration. Journal of Purchasing \& Supply Management 21(1): 38-50, https://doi.org/10.1016/j.pursup.2014.08.003.

Eriksson PE and Leiringer R (2015) Explorative and exploitative learning in project-based organizations: improving knowledge governance through a project management office? Engineering Project Organization Journal 5(4): 160-179, https://doi.org/10.1080/21573727.2015.1104665.

Eriksson PE, Lingegård S, Borg L and Nyström J (2017a) Procurement of railway infrastructure projects - a European benchmarking study. Civil Engineering Journal 3(4): 199-213. 
Eriksson PE, Leiringer R and Szentes $\mathrm{H}$ (2017b) The role of co-creation in enhancing explorative and exploitative learning in project-based settings. Project Management Journal 48(4): 22-38, https://doi.org/10. $1177 / 875697281704800403$

Fabbe-Costes N and Jahre M (2007) Supply chain integration improves performance: the emperor's new suit? International Journal of Physical Distribution \& Logistics Management 37(10): 835-855, https://doi.org/10.1108/09600030710848941.

Fellows R and Liu A (2016) Sensemaking in the cross-cultural contexts of projects. International Journal of Project Management 34(2): 246-257, https://doi.org/10.1016/j.ijproman.2015.03.010.

Flynn B, Huo B and Zhao X (2010) The impact of supply chain integration on performance: a contingency and configuration approach. Journal of Operations Management 28(1): 58-71, https://doi.org/10.1016/j.jom. 2009.06.001.

Gil N (2009) Developing cooperative project client-supplier relationships: how much to expect from relational contracts? California Management Review 51(2): 144-169, https://doi.org/10.2307/41166484.

Gransberg D, Shane J, Strong K and Lopez del Puerto C (2013) Project complexity mapping in five dimensions for complex transportation projects. Journal of Management in Engineering 29(4): 316-326, https://doi.org/10.1061/(ASCE)ME.1943-5479.0000163.

Gupta A, Smith K and Shalley C (2006) The interplay between exploration and exploitation. Academy of Management Journal 49(4): 693-706, https://doi.org/10.5465/amj.2006.22083026.

Han SH, Yun S, Kim H et al. (2009) Analyzing schedule delay of mega project: lessons learned from Korea Train eXpress. IEEE Transactions on Engineering Management 56(2): 243-256, https://doi.org/10.1109/ TEM.2009.2016042.

Hartmann A and Dorée A (2015) Learning between projects: more than sending messages in bottles. International Journal of Project Management 33(2): 341-351, https://doi.org/10.1016/j.ijproman.2014. 07.006

Harty C (2005) Innovation in construction: a sociology of technology approach. Building Research \& Information 33(6): 512-522, https:// doi.org/10.1080/09613210500288605.

Hoezen M and Volker L (2015) The importance of procurement negotiations for project success. IPMA Projectie Magazine 2015(1): 2-8.

Johansen K, Comstock M and Winroth M (2005) Coordination in collaborative manufacturing mega-networks: a case study. Journal of Engineering and Technology Management 22(3): 226-244, https://doi. org/10.1016/j.jengtecman.2005.06.005.

Kadefors A, Björlingson E and Karlsson A (2007) Procuring service innovations: contractor selection for partnering projects. International Journal of Project Management 25(4): 375-385, https://doi.org/10. 1016/j.ijproman.2007.01.003.

Kähkönen K (2015) Role and nature of systemic innovations in construction and real estate sector. Construction Innovation 15(2): 130-133, https://doi.org/10.1108/CI-12-2014-0055.

Koppenjan J, Veeneman W, van der Voort $\mathrm{H}$, ten Heuvelhof $\mathrm{E}$ and Leijten $\mathrm{M}$ (2011) Competing management approaches in large engineering projects: the Dutch RandstadRail project. International Journal of Project Management 29(6): 740-750, https://doi.org/10.1016/j. ijproman.2010.07.003.

Larsson L and Larsson J (2018) Sustainable development in project-based industries - supporting the realization of explorative innovation. Sustainability 10(3): article 683, https://doi.org/10.3390/su10030683.

Lenferink S, Arts J, Tillema T, van Valkenburg M and Nijsten R (2012) Early contractor involvement in Dutch infrastructure development: initial experiences with parallel procedures for planning and procurement. Journal of Public Procurement 12(1): 1-42, https://doi org/10.1108/JOPP-12-01-2012-B001.

March J (1991) Exploration and exploitation in organizational learning. Organization Science 2(1): 71-87, https://doi.org/10.1287/orsc.2.1.71.
Martinsuo M and Ahola T (2010) Supplier integration in complex delivery projects: comparison between different buyer-supplier relationships. International Journal of Project Management 28(2): 107-116, https:// doi.org/10.1016/j.ijproman.2009.09.004

Ozorhon B (2013) Analysis of construction innovation process at project level. Journal of Management in Engineering 29(4): 455-463, https:// doi.org/10.1061/(ASCE)ME.1943-5479.0000157.

Rose T and Manley K (2012) Adoption of innovative products on Australian road infrastructure projects. Construction Management and Economics 30(4): 277-298, https://doi.org/10.1080/01446193.2012.665173.

Rose T and Manley K (2014) Revisiting the adoption of innovative products on Australian road infrastructure projects. Construction Management and Economics 32(9): 904-917, https://doi.org/10.1080/ 01446193.2014 .938670$.

Roumboutsos A and Saussier S (2014) Public-private partnerships and investments in innovation: the influence of the contractual arrangement. Construction Management and Economics 32(4) 349-361, https://doi.org/10.1080/01446193.2014.895849.

Stake R (1995) The Art of Case Research. Sage, Thousand Oaks, CA, USA.

Tawiah P and Russell A (2008) Assessing infrastructure project innovation potential as a function of procurement mode. Journal of Management in Engineering 24(3): 173-186, https://doi.org/10.1061/(ASCE)0742597X(2008)24:3(173).

Verweij S (2015) Achieving satisfaction when implementing PPP transportation infrastructure projects: a qualitative comparative analysis of the A15 Highway DBFM Project. International Journal of Project Management 33(1): 189-200, http://doi.org/10.1016/j. ijproman.2014.05.004.

Volker L (2012) Procuring architectural services: sensemaking in a legal context. Construction Management and Economics 30(9): 749-759, https://doi.org/10.1080/01446193.2012.667138.

Volker L and Hoezen M (2017) Client learning across major infrastructure projects. In Clients and Users in Construction: Agency, Governance and Innovation (Haugbølle K and Boyd D (eds)). Routledge, London, UK, pp. 139-153.

van Wijck DJA (2018) Early Contractor Involvement in the Netherlands the Potential of ECI in Public Construction Projects. MSc thesis, Delft University of Technology, Delft, the Netherlands. See http://resolver. tudelft.nl/uuid:d72e722f-fd17-4645-8e5d-821 ce5520f39 (accessed 29/08/2019)

WEF (World Economic Forum) (2016) Shaping the Future of Construction: a Breakthrough in Mindset and Technology. WEF, Cologny, Switzerland. See http://www3.weforum.org/docs/ WEF_Shaping_the_Future_of_Construction_full_report_.pdf (accessed 01/04/2019).

Winch G (2013) Escalation in major projects: lessons from the channel fixed link. International Journal of Project Management 31(5): 724-734, https://doi.org/10.1016/j.ijproman.2013.01.012.

\section{How can you contribute?}

To discuss this paper, please email up to 500 words to the editor at journals@ice.org.uk. Your contribution will be forwarded to the author(s) for a reply and, if considered appropriate by the editorial board, it will be published as discussion in a future issue of the journal.

Proceedings journals rely entirely on contributions from the civil engineering profession (and allied disciplines). Information about how to submit your paper online is available at www.icevirtuallibrary.com/page/authors, where you will also find detailed author guidelines. 